JOSHUA CHARLES RAYMOND AIRD

\title{
DISCRIMINATION ON THE GROUNDS OF SEXUAL ORIENTATION: A COMPARISON BETWEEN THE UNITED KINGDOM AND NEW ZEALAND
}

Submitted for the LLB (Honours) Degree

Faculty of Law

Victoria University of Wellington 


\begin{abstract}
:
This paper compares the way in which the United Kingdom and New Zealand approach discrimination claims on the ground of sexual orientation. This paper uses the recent judgment in the case of Bull v Hall as an avenue to explore this issue contrasting it with a similar fact situation in New Zealand, the Pilgrim Planet Lodge discrimination. This paper illustrates that the majority in Bull v Hall were able to take a substantive equality approach to their reasoning. This approach is the most consistent with the principle of nondiscrimination. The paper then focuses on the legislative and process differences in the United Kingdom and New Zealand and the results they produce. Finally by looking and the advantages and disadvantages of both approaches this paper concludes that to build a human rights culture and respect the principle of non-discrimination there needs to be more availability of pubic litigation of discrimination claims.
\end{abstract}

Key words: Bull v Hall, Discrimination, The New Zealand Bill of Rights Act, The Human Rights Act, Sexual Orientation. 


\section{Table of Contents}

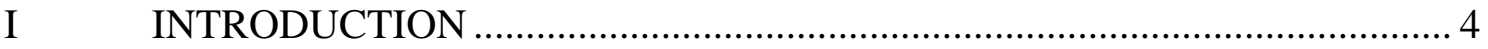

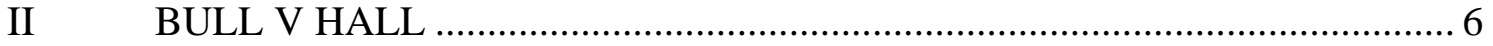

A The Events Leading to a Claim of Discrimination ........................................ 6

B Basis of the Claim and Procedural History ................................................... 7

C Supreme Court Decision.......................................................................... 9

$1 \quad$ Direct or Indirect Discrimination ................................................... 9

$2 \quad$ Justifiability of Indirect Discrimination ......................................... 13

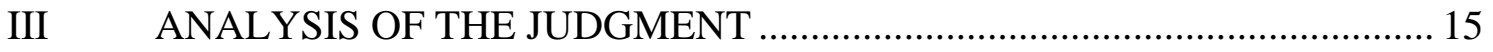

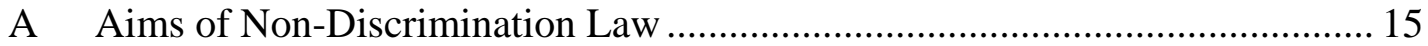

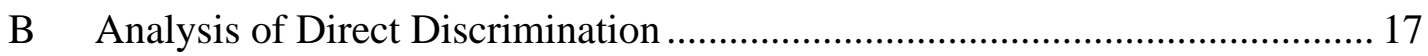

C Analysis of Justification of Indirect Discrimination...................................... 21

IV COMPARISON OF NON-DISCRIMINATION LAWS AND PROCESSES

A Legislative Comparison ........................................................................ 22

B Process.......................................................... 25

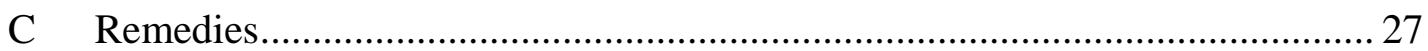

D Pilgrim Planet Lodge: A Case Study ......................................................... 27

$\mathrm{V}$ IS THERE A PREFERRED APPROACH TO DISCRIMINATION

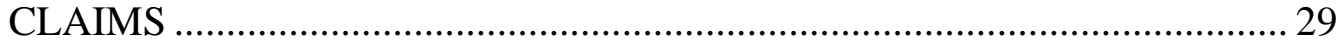

A Litigation or Mediation: What is the Preferred Approach? ............................. 29

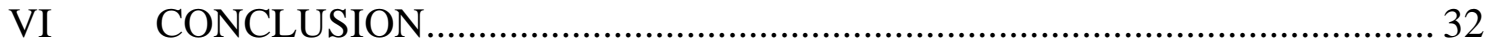

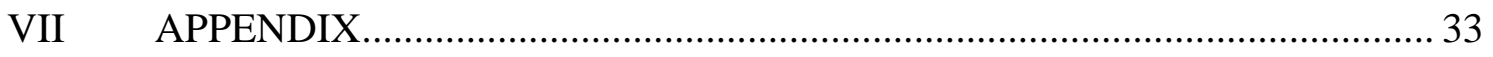

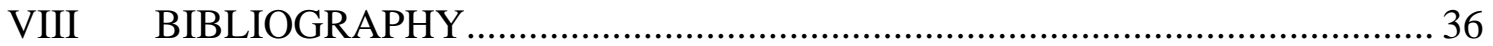




\section{Introduction}

The late Nelson Mandela once championed that "to deny any person their human rights is to challenge their very humanity." ${ }^{1}$ The human rights debate, in particular the rights of non-heterosexuals, ${ }^{2}$ has moved to the forefront of public debate in New Zealand and the United Kingdom. The recent passage of numerous pieces of legislation has recognised the insidiousness of discrimination on the grounds of sexual orientation. ${ }^{3}$ The moral compass has swung in favour of recognising and respecting the individuality of all people. Legislatures have deemed that individual expression of sexual orientation should not be a legitimate basis for discrimination. New Zealand and the United Kingdom have been resolute in their condemnation of discrimination on the grounds of sexual orientation, there are however, differences between how the two jurisdictions deal with claims of discrimination.

In this paper, I will discuss the different approaches to the resolution of discrimination complaints on the basis of sexual orientation. The recent judgment of the United Kingdom's Supreme Court in Bull $v$ Hall, a case of discrimination against a nonheterosexual couple at a private hotel, ${ }^{4}$ has propelled the discrimination dispute resolution

$1 \quad$ Nelson Mandela (Speech to Joint Meeting of the Unites States Congress 26 June 1990).

2 Throughout this paper the term non-heterosexual is used instead of many other terms that could have been used for queer sexual orientations. The reasons for this are threefold. First, from a purely practical perspective, using 'non-heterosexual' and its derivatives leads to consistency of terminology throughout the paper. Second, I wanted to avoid the sterile nature and negative connotations of 'homosexuality' and 'homosexual'. Third, I wanted to be inclusive in this paper. The issues surrounding discrimination are not just confined to gay men, they are pervasive throughout the queer community and I intend to be inclusive while writing this paper. I recognise that non-heterosexual is not a term that everyone in the community uses or identifies with, the confines of academic writing however, require a choice to be made.

3 Civil Partnership Act 2004 (UK); Marriage (Same Sex Couples) Act 2013 (UK); Civil Union Act 2004; Marriage (Definition of Marriage) Amendment Act 2013. See also the repeal of s 28 of the Local Government Act 1988 (UK) in 2003, that act stated local authorities "shall not intentionally promote homosexuality or publish material with the intention of promoting homosexuality" or "promote the teaching in any maintained school of the acceptability of homosexuality as a pretended family relationship".

$4 \quad$ Bull v Hall [2013] UKSC 73 [2013] 1 WLR 3741. 
process into the national media. ${ }^{5}$ Much has been made of the ability of the nation's highest court to make a public pronouncement of the legality of particular policies. This sits in stark contrast to an analogous case in New Zealand, the Pilgrim Planet discrimination. This case concerned discrimination against a non-heterosexual couple at a Whangarei Bed and Breakfast.

The fundamental premise of this paper is that there needs to be an increase recognition of non-heterosexual rights, in particular when they conflict with religious rights. In this respect in Part II of this paper I will discuss the judgment of Bull v Hall, in order to illustrate the United Kingdom's approach. Included in this will be a brief discussion of the procedural history of the case and the relevant legislation.

In Part III of this paper I will analyse the effectiveness of this judgment in achieving the aims of the principle of non-discrimination. To do this I will start with encapsulating the fundamental aims of the principle. I will then explore this through the lens of the judgment of Bull v Hall. Concluding that the majority was correct in its interpretation of the law and recognising the legitimacy of non-heterosexual relationships and the rights ascribed to them.

I will then explore the difference between the two jurisdictions. In Part IV I will first embark on a threefold comparison. First the legislative mechanisms, through which discrimination on the ground of sexual orientation is achieved will be compared. Second, the process of resolving disputes, contrasting the mediation of disputes in New Zealand and the litigation focus in the United Kingdom. Finally comparing the remedies available. This will provide the basis for further discussion of the Pilgrim Planet discrimination.

$5 \quad$ See for example: “Bristol Gay Couple Win Cornwall B\&B Bed Ban Case” BBC (online ed, London, 18 January 2011); “Gay Couple Awarded Damages after Christian Hotel Owners Refused to Let Them Share Double Room” The Telegraph (online ed, London, 18 January 2011) and Steve Doughty and Anna Edwards “B\&B Owners' Right to Bar Gay Couple Crushed by 'Need to Fight Discrimination’ Mail Online (online ed, London, 27 November 2013). 
In Part V of this paper I will broaden the discussion to what each approach achieves. This will focus on the need that will be identified in Part IV, building a rights culture. I will compare the advantages and disadvantages of both approaches. Concluding that in order to truly accomplish the aims of the principle of non-discrimination there needs to be a more open resolution of discrimination complaints.

\section{Bull v Hall}

In order to fully illustrate the United Kingdom's approach to discrimination, this part of the paper will focus on the judgment of Bull $v$ Hall. First traversing the legislation and facts at issue in the case. The reasoning of the lower courts and their interpretation of the legislation will then be set out before moving on to the Supreme Court's judgment.

\section{A The Events Leading to a Claim of Discrimination}

Mr Preddy and Mr Hall ("the Preddy-Halls”) were civil partners who lived in Bristol. In September 2008 they booked a weekend away at the Bull's Chymorvah Private Hotel in Marazion, Cornwall. Mr and Mrs Bull, who owned the Hotel with their cousin Mr Quinn, were devout Christians and believed that the "only divinely ordained sexual relationship is that between a man and a woman within the bonds of matrimony."6 The Bulls advertised their policy, of only letting double-bedded rooms to heterosexual married couples, on their booking website which stated: ${ }^{7}$

Here at Chymorvah we have few rules, but please note, that out of a deep regard for marriage we prefer to let double accommodation to heterosexual married couples only - thank you.

This policy disclaimer was not seen by the Preddy-Halls however, as their booking was made by Mr Preddy by telephone and Mrs Bull did not follow her usual practice of asking by whom the room was to be occupied. ${ }^{8}$ When the Preddy-Halls arrived at the Hotel on 5

At [9] per Hale LJ.

At [9] per Hale LJ.

At [10] per Hale LJ. 
September they were told that they could not stay as the double-bedded rooms were for married couples only. The Preddy-Halls explained that they were in a civil partnership. $\mathrm{Mr}$ Quinn responded that as the Bulls and he were devout Christians they did not believe in civil partnerships, recognising only marriage between a man and a woman. ${ }^{9}$ Although not done in a demeaning manner, this was "very hurtful" to the Preddy-Halls as there were other guests present. ${ }^{10}$ The Preddy-Halls sought alternative accommodation.

\section{B Basis of the Claim and Procedural History}

The proceedings were initially launched in the Bristol County Court with the assistance of the Equality and Human Rights Commission ("the UK Commission”) after the Bulls rejected the contention that they had discriminated against the Preddy-Halls. The case was brought under the Equality Act 2006 (UK). The Act established the UK Commission and extended previous prohibitions of discriminatory treatment to, among other things, the provision of goods, facilities and services. ${ }^{11}$ Sexual orientation became a prohibited ground of discrimination through the Equality Act (Sexual Orientation) Regulations 2007 (UK) ("the Regulations"). ${ }^{12}$ The key issue for the purpose of this paper was whether the policy amounted to direct or indirect discrimination. This is the key issue as it helps to identify what approach the Court takes to the principle of non-discrimination.

The United Kingdom employs a distinction between direct and indirect discrimination. It is not that direct discrimination can never be justified it is simply that all justifications are expressed in the legislation. It can also become more important when there is a clash of two competing rights. ${ }^{13}$ Direct discrimination is where one person treats another less favourably on the grounds of a protected characteristic under the legislation. ${ }^{14}$ While

\footnotetext{
$9 \quad$ At [10] per Hale LJ.

10 At [10] per Hale LJ.

11 At [3] per Hale LJ.

12 Equality Act (Sexual Orientation) Regulations 2007 (UK), reg 4(1).

13 Lady Hale “The Conflict of Equalities” (Alison Weatherfield Memorial Lecture, Employment Lawyers Association, 10 July 2008).

14 Equality Act (Sexual Orientation) Regulations (UK), reg 3(1).
} 
indirect discrimination can be characterised as a policy or practice that is prima facie neutral yet leads to an adverse impact on a protected group. ${ }^{15}$ It was acknowledged many times that this distinction is not easily defined. ${ }^{16}$

In the United Kingdom non-discrimination law must be read in a manner compatible with the right to religious freedom under the European Convention of Human Rights ("the ECHR”). ${ }^{17}$ The Human Rights Act 1998 (UK) imposes a positive obligation on the courts to interpret all legislation compatible with the ECHR. This includes, relevant to this case, art 9 of the ECHR - the right to manifest religion without unjustified limitation by the state and art 14 of the ECHR - the right to enjoy the rights under the ECHR (specifically art 8, the right to respect of private life) without unjustified discrimination on the grounds of sexual orientation. Regulations incompatible with the ECHR can be ignored. ${ }^{18}$

In the Bristol County Court his Honour Judge Rutherford held that the discrimination was direct. $^{19}$ When considering whether or not the Regulations were incompatible with the Bulls' rights under the ECHR, his Honour held that in so far as the Regulations affect the Bulls' right to freedom of religion it is “a necessary and proportionate intervention by the state to protect the rights of others."20 His Honour further held that if he was wrong and this was in fact a case about indirect discrimination the discrimination would not be justified. $^{21}$

$15 \quad$ Michael Connolly Discrimination Law (Sweet \& Maxwell, London, 2011) at 153; Schnorbus v Land Hessen (Case C-79/99) [2000] ECR I-10997 at [33]; Karon Monaghan Equality Law (Oxford University Press, Oxford, 2007) at 10 and Equality Act (Sexual Orientation) Regulations (UK), reg 3(3).

16 Bull v Hall, above n 4, at [16] per Hale LJ, [64] per Toulson LJ and Hall v Bull [2011] EW Misc 2 (CC) (04 January 2011) at [26].

17 Human Rights Act 1998 (UK), s 3.

18 Human Rights Act (UK), s 3.

19 At [37].

20 At [39].

$21 \quad$ At [54]. 
The Bulls appealed to the Court of Appeal. The appeal was dismissed with the Court finding that the Bulls' actions amounted to direct discrimination on the grounds of sexual orientation. The Court was convinced by the Preddy-Halls’ argument that a married couple was the correct comparator group for a couple in a civil partnership due to reg 3(4). ${ }^{22}$ The legislature had made clear that this was the purpose of the provision and this decision would help to enable the legislation to have its desired effect. ${ }^{23}$ The Court also held that the limitation on the Bulls' rights under art 9 of ECHR was necessary in a democratic society for the protection of others. ${ }^{24}$ The Bulls then appealed to the Supreme Court.

\section{Supreme Court Decision}

The appeal to the Supreme Court focused on three main issues. ${ }^{25}$ The first issue was whether this was a case of direct or indirect discrimination on the ground of sexual orientation. Secondly, if it was indirect discrimination whether the policy was justified under regulation 3(3)(d). Thirdly, if it was unlawful discrimination (direct or indirect and unjustified) whether the Regulations must be "read and given effect" to comply with the Bulls’ ECHR rights. ${ }^{26}$

\section{Direct or Indirect Discrimination}

The majority held that this was a case of direct discrimination. Lady Hale acknowledged that at first glance that this may not be direct discrimination as "while all same sex couples were denied, so too were some opposite sex couples [those not married].”27 The difference lay in the fact that the Preddy-Halls were in a civil partnership which proved crucial to the majority’s reasoning. ${ }^{28}$

\footnotetext{
$22 \quad$ Bull v Hall [2012] EWCA Civ 83 [2012] 1 WLR 2514 at [39] per Rafferty LJ.

23 At [38] per Rafferty LJ; Equality Act (Sexual Orientation) Regulations (UK), Explanatory note.

$24 \quad$ At [51] per Rafferty LJ.

25 At [15] per Hale LJ.

$26 \quad$ Human Rights Act (UK), s 3.

27 At [21] per Hale LJ.

28 At [25] per Hale LJ.
} 
In 2008 when the discriminatory actions took place it was not possible for same sex couples to enter into marriage. ${ }^{29}$ In place of marriage the United Kingdom Parliament created the institution of civil partnerships, which was solely reserved for same sex couples. ${ }^{30}$ Lady Hale recognised that this was not just a contractual relationship between two parties. When a couple entered into a civil partnership there was a change in status and this status carried with it rights and obligations that were indistinguishable from those impressed on married couples. $^{31}$ The equivalence of status is also illustrated by the Regulations which instructed that the fact that one person was married and the other in a civil partnership should not be a material difference. ${ }^{32}$

It is important to note that reg 3(4) does not turn what would otherwise be indirect discrimination into direct discrimination, as it applies to both types of discrimination, it serves a different function. ${ }^{33}$ Lady Hale recognised that reg 3(4) directs that "people who are married and people who are civil partners are to be regarded as similarly situated.”34 Lady Hale agreed with the Court of Appeal that the appropriate comparator group to a couple in a civil partnership was a married couple. ${ }^{35}$ Since marriage is reserved for heterosexual couples only, distinguishing discrimination based on marital status and discrimination based on sexual orientation is difficult. Lady Hale said that there is an "exact correspondence between the advantage conferred and the disadvantage imposed in allowing a double bed to the one and denying it to the other."36 The Bulls' policy was absolute in relation non-heterosexuals but not in relations to heterosexuals and it therefore

\footnotetext{
29 This has since been amended with the passage of the Marriage (Same Sex Couples) Act 2013 (UK). $30 \quad$ Civil Partnership Act (UK), s 3.

31 Bull v Hall, above n 4, at [26] per Hale LJ and Nicholas Bamforth, Maleiha Malik and Colm O’Cinneide Discrimination Law: Theory and Context (Sweet \& Maxwell, London, 2008) at 735.

32 Equality Act (Sexual Orientation) Regulations (UK), reg 3(4).

33 At [27] per Hale LJ.

34 At [27] per Hale LJ.

35 Bull v Hall, above n 4, at [27] per Hale LJ; Bull v Hall (CA), above n 22, at [37] per Rafferty LJ and Clare Fenton-Glynn "Replacing One Type of Oppression with Another? Same-Sex Couples and Religious Freedom” (2014) 73(1) CLJ 31 at 33.

36 At [29] per Hale LJ.
} 
discriminates against the Preddy-Halls because of their sexual orientation. Put another way, the criterion at the heart of the restriction that the Preddy-Halls should be married is necessarily linked with their sexual orientation. Once it is accepted that the civil partnership entitled the Preddy-Halls to be treated in the same way as a married couple, the only remaining basis for the difference in treatment was the Preddy-Halls' sexual orientation. ${ }^{37}$

Even without reg 3(4), directing the court to treat civil partnerships the same as marriage, Lady Hale, and possibly Lord Toulson, ${ }^{38}$ would have struggled to find that this was anything other than direct discrimination. ${ }^{39}$ They argued that as marriage is only for opposite sex couples and civil partnerships are solely reserved for same sex couples, it is hard to justify that entering into of a civil partnership would do nothing. It is an analogous status to marriage and can only be seen to direct the court to a comparison with a married couple for the purposes of discrimination. ${ }^{40}$ Lord Kerr would not have agreed with Lady Hale, the effect of reg 3(4) was to identify the correct comparator group, if this was not in place then it would have been indirect discrimination. ${ }^{41}$ His Lordship was not prepared to treat marriage and civil partnerships the same without direction from Parliament. Lord Kerr was supported in this argument by the minority.

The minority held that this was not a case of direct discrimination. The minority held that rather than discrimination on the grounds of sexual orientation the Bulls were discriminating on the ground of marital status. Lord Neuberger held that because the Bulls would have treated any unmarried heterosexual couple the same way it is not possible to say that the reasons for the discrimination was their sexual orientation. ${ }^{42}$ In the view of the minority, reg 3(4) did not assist the Preddy-Halls’ argument, rather it is a circular or selffulfilling regulation as "it assumes that the purpose of [reg] 3(4) is to render discrimination

At [60] per Kerr LJ.

At [70] per Toulson LJ.

At [29] per Hale LJ.

Bull v Hall (CA), above n 22, at [37] per Rafferty LJ and Fenton-Glynn, above n 35, at 33.

At [62] per Kerr LJ.

At [76] per Neuberger LJ. 
in a case such as this direct, when that is the very question at issue." ${ }^{33}$ Lord Neuberger went on to say that there is no reason as a matter of policy or logic why civil partnerships should be treated the same as a marriage and if that was Parliament's intention then they would have been clearer. ${ }^{44}$ It was important for the minority to keep the law clear and not further muddy the already unclear distinction between direct and indirect discrimination. ${ }^{45}$

The majority argued that what matters is the effect of the policy, not the reasons for implementing the policy. ${ }^{46}$ The reasons may be relevant when assessing the justification of indirect discrimination but they will not be relevant when deciding between direct and indirect discrimination. Lord Hughes took exception to this and said that the majority focused incorrectly on a characteristic of the Preddy-Halls. ${ }^{47}$ His Lordship identified three sub groups of people that would all be affected by this policy; same sex couples in a civil partnership; same sex couples not in a civil partnership and opposite sex unmarried couples. ${ }^{48}$ His Lordship's argument was that if one were to treat heterosexuals the same as non-heterosexuals then this cannot be a case of direct discrimination as the protected characteristic of sexual orientation is not the reason for the discriminatory practice, it is being un-married.

The Court continued to reason in the alternative as the Bulls accepted that their policy was indirect discrimination. It obviously puts non-heterosexuals as a group at a serious disadvantage when compared with heterosexuals, as the Preddy-Halls cannot enter into a status which the Bulls regard as marriage. ${ }^{49}$ The Court had to decide whether if being indirect discrimination it was justified.

\footnotetext{
$43 \quad$ At [79] per Neuberger LJ.

$44 \quad$ At [80] per Neuberger LJ.

45 At [84] per Neuberger LJ.

46 Hale LJ, “The Conflict of Equalities”, above n 13.

47 At [89] per Hughes LJ.

48 At [90] per Hughes LJ.

49 At [33] per Hale LJ.
} 


\section{Justifiability of Indirect Discrimination}

The Bulls argued that the discrimination was indirect and that it was justified because of their deeply held religious beliefs. They did not think that they should be compelled to run their business in a way that facilitated, what they viewed as, $\sin ^{50}$ The Court rejected this argument. Taken to its logical conclusion it would mean that a subset of individuals, to whom discrimination laws did not apply, would be created. There are already exceptions in the Regulations which allow for discriminatory practice, these exceptions cover those who take other people into their own home and treat as members of the family, ${ }^{51}$ and religious organisations. ${ }^{52}$ The legislature has instructed that non-heterosexuals should not be treated any differently than their heterosexual counterparts except for carefully considered exceptions already expressed in statute. The same goes for religious individuals, they cannot be treated any differently because of their religious beliefs. If a nonheterosexual couple refused to let a room to a religious couple they too could be brought before the courts under discrimination law. More importantly, the judgment is not casting doubt on the legality of the Bulls' belief that non-heterosexual sexual relationships are sinful, the Court stated many times that this was the an opinion that was genuinely held. It is the expression and manifestation of the belief which treats a group of people less favourably that is unlawful. ${ }^{53}$

Article 9 of the ECHR protects the Bulls’ right to freedom of religion. This right is subject to an internal qualifier which allows for limitations on the right that are prescribed by law and necessary in a democratic society for amongst other things the protection of the rights of others. ${ }^{54}$ In a pluralist society it is inevitable the beliefs and rights of some will not be compatible with others. ${ }^{55}$ The Court agreed that the Bulls are free to hold and manifest their beliefs in many different ways. They are prohibited, however, from doing so in the

\footnotetext{
$50 \quad$ Bull v Hall, above n 4, at [34] per Hale LJ.

$51 \quad$ Equality Act (Sexual Orientation) Regulations (UK), reg 6(1).

52 Equality Act (Sexual Orientation) Regulations (UK), reg 14.

53 Bull $v$ Hall, above $n$ 4, at [37] per Hale LJ.

$54 \quad$ European Convention on Human Rights, art 9(2).

55 Bull $v$ Hall (CA), above n 22, at [56] per Rafferty LJ.
} 
commercial context they have chosen. ${ }^{56}$ The purpose or motive of the policy is irrelevant, as Lord Kerr said ${ }^{57}$

[W]e do not normally allow people to behave in a way which the law prohibits because they disagree with the law. But to allow discrimination against persons of homosexual orientation ... because of a belief, however sincerely held, and however based on the biblical text, would be to do just that.

The ordinary law gives the Preddy-Halls the right to be free from discriminatory practices and is considered necessary, so the question becomes whether the encroachment on the freedom of religion is 'proportionate'. 58

The Court as a whole was prepared to accept that the concept of "reasonable accommodation" is part of the proportionality assessment when justifying indirect discrimination. ${ }^{59}$ Although the Bulls had offered a reimbursement of the deposit, had not acted in a demeaning manner and were prepared to offer the Preddy-Halls a twin bed room the Court held that there was no avoiding that what the Bulls did was prohibited by law. ${ }^{60}$ The reason for this was that "sexual orientation is a core component of a person's identity which requires fulfilment through relationships with others of the same orientation."61 Expressions of sexuality require a partner, whether they are real or imagined. ${ }^{62}$ In the Court's view, very weighty reasons are required to justify discrimination on the grounds of sexual orientation. ${ }^{63}$ These reasons were not present in this case.

\footnotetext{
$56 \quad$ Bull $v$ Hall (CA), above n 22, at [56] per Rafferty LJ.

$57 \quad$ Bull v Hall, above n 4, at [61] per Kerr LJ. See generally Bull v Hall, above n 4, at [37] per Hale LJ; Bull v Hall (CA), above n 22; James v Eastleigh Borough Council [1990] 2 AC 751 and R (E) v Governing Body of JFS School [2009] UKSC 15 [2010] 2 AC 728.

$58 \quad$ Bull $v$ Hall, above n 4, at [45] per Hale LJ.

59 At [47] per Hale LJ.

60 At [50] to [52] per Hale LJ.

$61 \quad$ Bull $v$ Hall, above $\mathrm{n} 4$, at [52] per Hale LJ.

$62 \quad$ National Coalition for Gay and Lesbian Equality $v$ Minister of Justice 1999 (1) SA 6 at [117] per Sachs J.

63 At [53] per Hale LJ.
} 


\section{Analysis of the Judgment}

When analysing the judgment it will become clear that the majority was correct in categorising this as a case of direct discrimination. The majority's approach was consistent with accepting that non-heterosexual relationships are worthy of equal respect as heterosexual relationships. The minority, branding the discrimination as indirect, was excessively focused on black letter law. Determined to solidify the difference between nonheterosexuals and heterosexuals and the rights they hold. As will become clear the aims of the principle non-discrimination demand a more substantive equality.

\section{A Aims of Non-Discrimination Law}

Butler and Butler describe the principle of non-discrimination as being central in a democratic society "where each individual is valued as a person, worthy of dignity and respect." ${ }^{\text {64 }}$ In this regard the principle of non-discrimination aims to promote equality of treatment. I will focus on two possible formulations of this principle, each with its own merits. First formal equality, treating all people equally, the standard and results of which are not of concern. Second substantive equality which "demands that social justice and equality is meaningful and real to disadvantaged groups.”65

Formal equality only demands that two groups of people are treated the same. The equality of law "which forbids the rich as well as the poor to sleep under bridges". ${ }^{66}$ The proliferation of this doctrine was demonstrated in the United States of America with the separate but equal doctrine. ${ }^{67}$ Formal equality is approached with a view of equality set by men, and is strict in its application of equal treatment not more favourable treatment. The fact that either Mr Preddy or Mr Hall could have stayed at the Bulls' hotel, if married to a

\footnotetext{
$64 \quad$ Andrew Butler and Petra Butler The New Zealand Bill of Rights Act: A Commentary (Lexis Nexis, Wellington, 2005) at 483.

65 Connolly, above n 15, at 11.

66 Sandra Fredman Discrimination Law (2nd ed, Oxford University Press, Oxford, 2011) at 1 citing Anatole France Le Lys Rouge (Calmann-Levy, Parris, 1972) at 106.

$67 \quad$ Connolly, above n 15 , at 10 .
} 
woman, would have satisfied formal equality ${ }^{68}$ Either parties could have married, if they made a choice not to do so, as Gault J seemed to reason in Quilter, then they would have chosen the discrimination. ${ }^{69}$ Or perhaps more drastically if a female non-heterosexual couple were also refused service then this would be equal treatment and not discriminatory, as both non-heterosexual men and women were treated identically. ${ }^{70}$ This is because the law is concerned with treating like as like. ${ }^{71}$ There is less room for an individualised comparator group. ${ }^{72}$ A notion of equality which stresses equal opportunities is consistent with inequality of treatment and inequality of results. ${ }^{73}$

Substantive equality would demand that both heterosexual and non-heterosexual couples are accepted in the hotel. It recognises the difference in the individuals, rather than removing or avoiding the difference, and removes the disadvantage imposed by that difference. ${ }^{74}$ Substantive equality suggests that the state has a role to play, as the cost of remedying the discriminatory treatment rests with society as a whole, and the state not doing anything may be seen as perpetuating the discrimination. ${ }^{75}$ I acknowledge that this may be a step too far in many cases, as the state should not be responsible for the acts of individual citizens. Substantive equality demands an equality of results in society, not just opportunity, which recognises that the starting point is not the same for all groups in society. The Preddy-Halls, as committed partners in a legally recognised partnership of mutual trust, love and respect, should be able to enjoy the same results as a married couple. ${ }^{76}$ There should be equal recognition of non-heterosexual and heterosexual relationships. ${ }^{77}$

\begin{tabular}{ll}
\hline 68 & Connolly, above n 15, at 7. \\
69 & Quilter v Attorney General [1998] 1 NZLR 523 at 527, per Gault J and Butler and Butler, above n \\
& 64, at 491. \\
70 & Connolly, above n 15, at 6. \\
71 & Connolly, above n 15, at 5. \\
72 & Connolly, above n 15 , at 6. \\
73 & Fredman, above n 66, at 2. \\
74 & Fredman, above n 66, at 30. \\
75 & Connolly, above n 15, at 11. \\
76 & Connolly, above n 15, at 13. \\
77 & Fredman, above n 66, at 86.
\end{tabular}




\section{B Analysis of Direct Discrimination}

The majority has been clear that the courts have a role in ensuring the discriminatory practices are not recognised as legitimate. In this section of the paper I will discuss why the majority's approach was the correct approach, acknowledging that the majority was right to recognise that non-heterosexual relationships deserve the same respect as heterosexual relationships under the law.

In 2008 when the discriminatory actions took place it was not possible for same sex couples to enter into marriage. ${ }^{78}$ In place of marriage the United Kingdom had the institution of civil partnerships, which was solely reserved for same sex couples. ${ }^{79}$ When introduced the Deputy Minister for Women and Equality explained this legislation as "a sign of the Government's commitment to social justice and equality."80 Essentially, the Government was attempting to introduce 'gay marriage' although they avoided that phrase. ${ }^{81}$ This was not just a contractual relationship between two parties. When a couple entered into a civil partnership there was a change in status and this status carried with it rights and obligations that were indistinguishable from those impressed on married couples. ${ }^{82}$ By classing the Bulls’ policy as direct discrimination the majority has taken an important real world view of non-heterosexual rights and relationships, a view achieved through the imposition of substantive equality. ${ }^{83}$ It is not possible to separate the sexual orientation and the institution which people are permitted to enter, any less favourable treatment must be on the basis of sexual orientation. ${ }^{84}$

\footnotetext{
78 This has been amended with the passage of the Marriage (Same Sex Couples) Act (UK).

79 Civil Partnership Act (UK).

$80 \quad$ (12 October 2004) 425 GBPD HC 174.

81 Bamforth, Malik and O’Cinneide, above n 31, at 735.

82 Bull v Hall, above n 4, at [26] per Hale LJ and Bamforth Malik and O'Cinneide, above n 31, at 735.

83 See generally Laura-Jane Houghton "Same-sex Marriage: A Perfectionist Liberal Justification” (2000) 7 UCL Juris. Rev. 301.

84 Fenton-Glynn, above n 35, at 34
} 
Lady Hale rightfully rejected the contention that non-heterosexuals can enter into marriage. Although legally possible, to entertain this argument that a non-heterosexual man can marry a woman, thus avoiding the discriminatory policy, is demeaning and trivialises that individual's sexual orientation. A similar argument to this was accepted in New Zealand by Gault J in Quilter. ${ }^{85}$ Gault J did not accept that the restriction of marriage to a man and a woman only was discriminatory as "denial of choice always effects only those who wish to make the choice. It is not for that reason discriminatory" 86 Such logic and formal equality reasoning has since been rejected in New Zealand as it should be in the UK. ${ }^{87}$ One cannot separate the branding of the Preddy-Hall's relationship form their sexual orientation. ${ }^{88}$

The majority was alive to the fact that they have a role in 'safeguarding' rights. ${ }^{89}$ To recognise the respect that should be given to non-heterosexual relationships as legitimate and stable relationships that seek out love, support and partnership..$^{90}$ In this quest they are no different from people of heterosexual orientation and their relationships. ${ }^{91}$ Rather than perpetuating the discrimination of the law, the majority has recognised that one should not underestimate the continuing legacy of centuries of discrimination, even persecution, on the grounds of sexual orientation. ${ }^{92}$ The decision of the majority to class this discrimination as direct has not meant however, that the Bulls are not free to manifest their religion in other ways. They are still free to use religious symbolism in their facilities, free to allow religious sermons to take place and religious groups to use their facilities, they may even promote their religion in their establishment. ${ }^{93}$ Nevertheless, not every act inspired by a religious belief will be protected by art 9 of the ECHR. The convention does not apply to

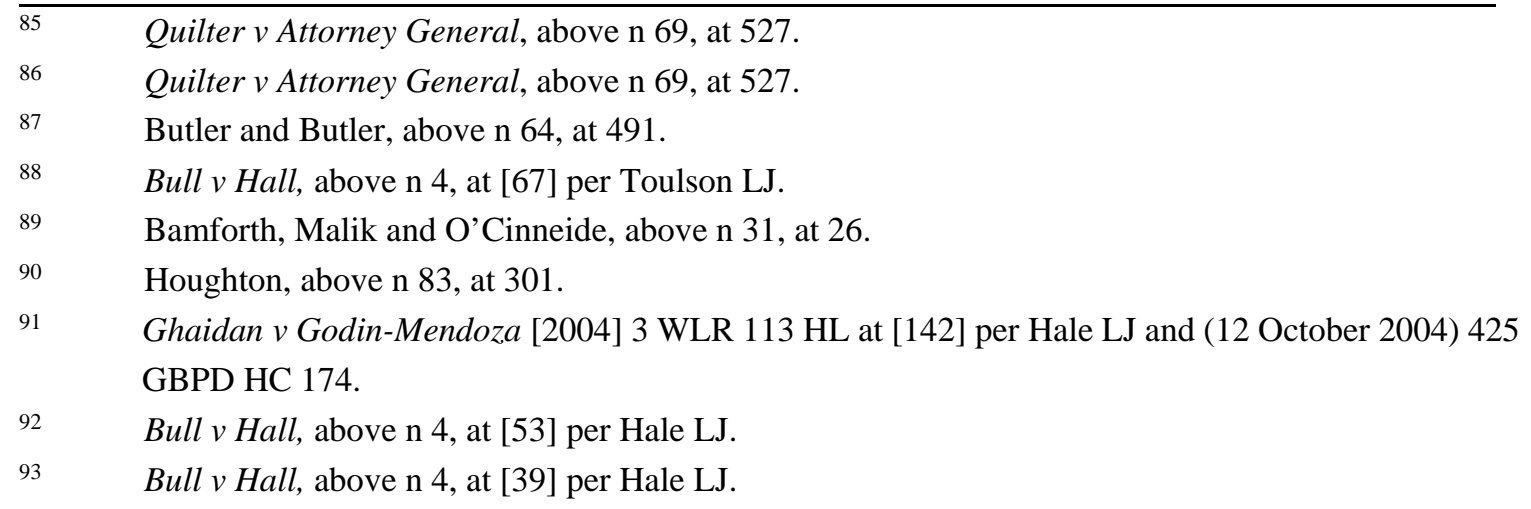


beliefs, no matter how honestly held, that are incompatible with human dignity. ${ }^{94}$ These are deemed to be outside of the scope of art 9 and not worthy of protection themselves considering the aim of the ECHR. ${ }^{95}$ The Court did not go so far as say that the Bulls' belief fit into this category, but the more that a right infringes on the rights of others the more likely any intrusion is going to be considered justified. ${ }^{96}$ The United Kingdom Parliament has recognised the tension that the Regulations may have with religious groups which is why they have dedicated an exception for "religious organisations" not for religious individuals more generally. This gives force to the argument that further concessions should be pragmatically advanced as Parliament did not consider it necessary. ${ }^{97}$

The minority was not convinced of the direct discrimination arguments. Lord Neuberger did not think that Parliament intended that civil partnerships and marriage should be given the same standing. This is a curious approach as Parliament expressly stated in the Regulations that civil partnerships and marriage should not be treated as materially different when assessing a discriminatory practice. ${ }^{98}$ Hansard debates show that the Government was trying to do was give non-heterosexual couples the same standing as married couples, albeit with a different label. ${ }^{99}$

Both the majority and minority acknowledged that reg 3(4) did not create direct discrimination where there is none, rather it gives guidance as to the appropriate

94 R(Williamson) $v$ Secretary of State for Education and Employment [2005] UKHL 15, [2005] 2 AC 246 at [23] per Nicholls J; Monaghan, above n 15, at 153 and James Dingemans, Can Yeginsu, Tom Cross and Hafsah Massod The Protections for Religious Rights: Law and Practice (Oxford University Press, Oxford, 2013) at [3.18].

95 Dinhemans, Yegunsu, Cross and Massod, above n 94, at [3.18] and Campbell and Cosans v UK (1982) 4 EHRR 293 at [36].

$96 \quad$ Monaghan, above n 15, at 153.

$97 \quad$ Bull $v$ Hall, above n 4, at [38] per Hale LJ.

98 Equality Act (Sexual Orientation) Regulations (UK), reg 3(4); since reinforced by the Equality Act 2010 (UK), s 23(3).

99 (12 October 2004) 425 GBPD HC 174; (24 June 2004) 662 GBPD HL 1354-91 and Bamforth, Malik and O’Cinneide, above n 31, at 735. 
comparator group. ${ }^{100}$ It emphasises that when approaching the question of direct or indirect discrimination, one must not consider a difference in the status of marriage and civil partnership. This in turn exposes the appropriate comparator group. By casting the comparator as all unmarried couples Lord Neuberger has ignored the status change in the Preddy-Halls from entering into a civil partnership. Lord Neuberger has built in a "tacit acceptance of a disputed policy at too early a stage and artificially removes the disputed point of discrimination.”101 Parliament attempted to promote stability and equality, Lord Neuberger has ignored the real world trials of non-heterosexual couples.

Lord Hughes reasoned that the correct approach to non-discrimination legislation was to focus on the discriminator's reasons for treating the discriminated as they did. It is not the intention of the parties that is relevant however, it is the effect of the policy, practice or criterion that is adopted. ${ }^{102}$ Relying on a subjective position to determine a discriminatory practice would frustrate the law's purpose. ${ }^{103}$ Rather than producing objective equality, it would produce a subjective assessment of equality which might not be equal at all. Human rights are not a subjective entitlement but an inherent right of being human. ${ }^{104}$ The minority failed to take a real world view of the situation which non-heterosexuals find themselves. In effect the minority has rendered the status change as something less than marriage and nothing more than a de facto relationship between heterosexual partners, not recognising the same conditions exist between the two couples, just with a different title. ${ }^{105}$ When the

\footnotetext{
$100 \quad$ Fenton-Glynn, above n 35, at 33.

101 Vanessa Haggie "Premature Justification: The Place of Comparator Group Analysis in Discrimination Law in Canada and New Zealand” (LLM Research Paper, Victoria University of Wellington, 2012) at 13 and Asher Emanuel “To Whom Will Ye Liken Me, and Make Me Equal? Reformulating the Role of the Comparator in the Identification of Discrimination” (2014) 45 VUWLR 1 at 7. 15 at 343. See generally Birmingham City Council v Equal Opportunities Commission [1989] AC 1155 and James v Eastleigh Borough Council, above n 57.

Bamforth, Malik and O'Cinneide, above n 31 at 237.

See generally Butler and Butler, above n 64 and Paul Rishworth and others The New Zealand Bill of Rights (Oxford University Press, Oxford, 2003). Houghton, above n 83, at 318.
} 
case was decided there was no possibility of non-heterosexuals marrying, save for rejecting their inherent dignity and self-worth by marrying someone who does not share the same sexual orientation. ${ }^{106}$ The minority's approach is a result of the formal equality conception of non-discrimination law.

\section{Analysis of Justification of Indirect Discrimination}

The Bulls did not attempt to justify their discrimination on the ground of a real business need. ${ }^{107}$ Rather justification was sought on the basis of a conflict of rights and the reduction of their freedom of religion. ${ }^{108}$ The Court rejected this argument. The sexual orientation of a person is an intrinsic and fundamental aspect of that person's life. The Court recognised that very weighty reasons are required for justification of indirect discrimination on the ground of sexual orientation. ${ }^{109}$ The Bulls right to religion contained an internal qualification. ${ }^{110}$ It could be limited to ensure the rights of others were observed. The Bulls are able to express their rights in other ways such as religious imagery, religious services and renting their premises to church groups. Their right to religion did not however, allow them to discriminate against people based on that person's sexual orientation. This is not case of replacing one discrimination with another. The United Kingdom has recognised that there may be conflict between religion and non-heterosexual sexual orientation, and has legislated for express exceptions, ${ }^{111}$ similar to New Zealand not obliging celebrants to solemnise marriage which conflict with their religious beliefs. ${ }^{112}$ It is not the role of the courts to create further exceptions.

\footnotetext{
$106 \quad$ Houghton, above n 83, at 309.

$107 \quad$ Fredman, above n 66, at 193.

108 Bull v Hall, above n 4, at [34] per Hale LJ.

109 Bull $v$ Hall, above n 4, at [53] per Hale J.

110 European Convention of Human Rights, art 9.

111 Equality Act (Sexual Orientation) Regulations (UK), reg 14.

$112 \quad$ Marriage Act 1955, s 29.
} 


\section{Comparison of Non-Discrimination Laws and Processes}

The majority judgment in Bull $v$ Hall recognises the importance of substantive equality. With the majority holding the Regulations required the Court to treat a civil partnership and marriage the same. New Zealand courts have been slower to recognise this concept. In this part of the paper I will illustrate the differences in approach to the principle of nondiscrimination between the two jurisdictions. First I will do this by a threefold comparison of the non-discrimination regimes. I will then move on to exploring the Pilgrim Planet discrimination.

\section{A Legislative Comparison}

The New Zealand Bill of Rights Act 1990 ("BORA") affirms the right to be free from discrimination on the 13 grounds set out in the Human Rights Act 1993 ("the NZHRA"), which includes sexual orientation. ${ }^{113}$ The NZHRA prohibits action, such as the provision of goods and services, taken "by reason of" a prohibited ground, subject to express exceptions. ${ }^{114}$ Unlike the United Kingdom which defines both direct and indirect discrimination, ${ }^{115}$ neither BORA nor the NZHRA defines direct discrimination. The only legislative guidance is a negative definition of discrimination being any "[m]easures taken in good faith for the purpose of assisting or advancing persons or groups disadvantaged because of discrimination" not constituting discrimination and the definition of indirect discrimination in s 65 of the NZHRA. ${ }^{116}$

The New Zealand courts have had varying levels of success in interpreting discrimination. In Quilter three long term female couples appealed to the Court of Appeal that the Marriage Act 1955 did not allow for marriages between two persons of the same sex. ${ }^{117}$ The majority found that there was no discrimination on the basis of sexual orientation because it would

\footnotetext{
$113 \quad$ New Zealand Bill of Rights Act 1990, s 19.

$114 \quad$ Human Rights Act 1993, s 44.

115 Equality Act (Sexual Orientation Regulations) (UK), regs 3(1) and 3(3).

$116 \quad$ New Zealand Bill of Rights Act, s 19(2) and Human Rights Act, s 65.

117 Quilter v Attorney-General, above n 69, at 526 per Gault J.
} 
have been the same regardless of whether or not the applicants were of non-heterosexual orientation, i.e. heterosexual females attempting to gain benefits from marriage. ${ }^{118}$ Gault $\mathrm{J}$ also held that "denial of choice always affects those who wish to make the choice. It is not for that reason discriminatory". ${ }^{119}$ Which may be formal equality, all women can marry, as long as they choose to marry men, but it does not fit the standard of the more desirable substantive equality. Gault $\mathrm{J}$ held that because marriage, as a long standing convention, was between man and a woman it could not be discriminatory. ${ }^{120}$ Longevity of a practice however, does not make it non-discriminatory when assessed against human rights norms. ${ }^{121}$ Further AMM and KJO centred on the interpretation of 'spouse' in the Adoption Act 1955 and whether it could be read to include a de facto couple. ${ }^{122}$ The Court held that it could be read to include a heterosexual de facto couple but not a nonheterosexual one. The Court suggested that a non-heterosexual de facto couple was not a "stable and committed family unit". ${ }^{23}$ The Court attempted to further justify their reasoning by stating that there was no concession from the Attorney-General that there was unjustified discrimination against non-heterosexual couples as there was with heterosexual couples. ${ }^{124}$

It has now been recognised that a broad purposive approach should be taken when interpreting non-discrimination laws, keeping with the broader BORA interpretation approach. ${ }^{125}$ A rights consistent approach was adopted in Atkinson, where it was held that there is discrimination if the claimant is treated differently on a prohibited ground resulting in a material disadvantage. ${ }^{126}$ The United Kingdom requires that there be 'less favourable'

\footnotetext{
$118 \quad$ At 527 per Gault J.

$119 \quad$ At 527 per Gault J.

$120 \quad$ At 527 per Gault J.

$121 \quad$ Butler and Butler, above n 64, at 492 citing examples of criminalisation of birth control and sodomy.

122 Re application by AMM and KJO to adopt a child [2010] NZFLR 629 (HC).

123 At [36].

124 The Attorney-General did however make this concession which was further clarified in a memorandum to the court.

125 Butler and Butler above n 64 at 75; Paul Rishworth and others, above n 104, at 377 and Ministry of Health $v$ Atkinson [2012] NZCA 184, [2012] 3 NZLR 456 at [101].

126 Ministry of Health $v$ Atkinson, above n 125, at [136].
} 
treatment, ${ }^{127}$ which would incorporate the same negative concept, requiring invidious treatment, not mere differentiation. ${ }^{128}$ This may be a lower standard than New Zealand however, as New Zealand requires that the disadvantage conferred must be more than trivial, the de minimis rule. ${ }^{129}$ The de minimis rule is favoured in New Zealand as it prevents a trivialising of the right to discrimination claims. ${ }^{130}$

As with the United Kingdom's approach there is a requirement to identify the correct comparator group when assessing the discriminatory practice. While an in depth discussion of comparator group is outside the scope of this paper, one thing is important to note. ${ }^{131}$ There is a propensity to import justification into the identification of a comparator group, by framing the comparator too wide or drawing a conclusion that the two groups are not comparable. ${ }^{132}$ This is unappealing as it creates "decision making based on instinct rather than analysis". 133

When identifying a discriminatory practice, justification should not form part of the inquiry. Justification of a directly discriminatory practice is obtained through s 5 of BORA not through the framing of the policy itself. ${ }^{134}$ If the practice can be justified in a free and democratic society then the discriminatory practice will not be unlawful. There is no general limitation against direct discrimination on the basis of sexual orientation in the United Kingdom. When considering indirect discrimination however, if there is a good reason for the policy or it can be justified by reference to other matters it will not be discriminatory at all. ${ }^{135}$ Direct discrimination on the grounds of sexual orientation could

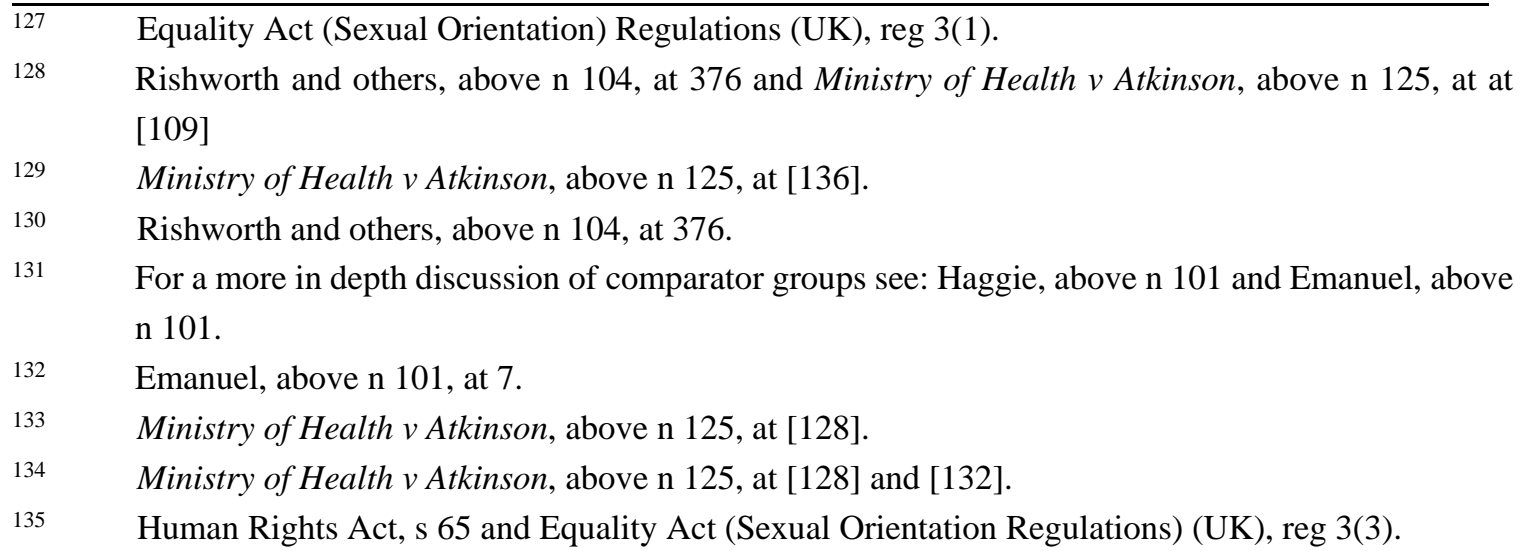


only be justified if one of the statutory exceptions was met. ${ }^{136}$ While there must be 'good reasons' for allowing indirect discrimination. Justification should not be sought through the comparator as this creates a weak rights culture as discrimination is less broadly defined and the right is limited which defeats the purpose of the act. ${ }^{137}$

\section{B Process}

Resolution of discrimination complaints is one of the core functions of both the New Zealand Human Rights Commission ("the NZHRC”) and the UK Commission. ${ }^{138}$ The NZHRC approaches this task in the most cost effective, efficient and informal manner. ${ }^{139}$ The NZHRC no longer has the ability to investigate a complaint and offers an alternative dispute resolution process instead. ${ }^{140}$ The UK Commission has the power to hold conciliation meetings, issue compliance notices, initiate investigations and initiate proceedings. $^{141}$

The NZHRC provides state funded mediation to parties of a discrimination complaint. ${ }^{142}$ In the 2013 annual report the NZHRC recorded that they received 1228 complaints alleging unlawful discrimination which were referred to mediation. ${ }^{143}$ Of these only 32 were complaints on the ground of sexual orientation. ${ }^{144}$ The dispute resolution process is designed to raise awareness of rights and responsibilities under the NZHRA, while encouraging discussion about the impact of discrimination. ${ }^{145}$ The NZHRC is not obliged

\footnotetext{
$136 \quad$ See generally Equality Act (Sexual Orientation Regulations) (UK).

$137 \quad$ Ministry of Health $v$ Atkinson, above n 125, at [128] and Emanuel, above n 101, at 7.

138 Human Rights Act, s76(1)(b); New Zealand Human Rights Commission “About the Human Rights Commission” <www.hrc.co.nz>; Equality Act (UK) 2006, s 3; and Equality and Human Rights Commission “Our Mission and Values” <www.equalityhumanrights.com>.

139 Attorney-General v Human Rights Review Tribunal (2006) 18 PRNZ 295 (HC) at [43] per Miller J. $140 \quad$ Human Rights Law Human Rights Act (online ed) at [76.02].

141 Equality Act 2006 (UK), Part 1.

142 The Laws of New Zealand Human Rights and Freedoms: Human Rights Act 1993 (online ed) at [203]. Human Rights Commission 2013 Annual Report at 18. Human Rights Commission 2013 Annual Report at 20. Human Rights Commission 2013 Annual Report at 21.
} 
to provide legal advice to parties during the dispute resolution process. ${ }^{146}$ Which may cause significant power imbalances or rights to be compromised. ${ }^{147}$ The dispute mediation is a confidential process between the parties. ${ }^{148}$ If the discrimination is trivial, vexatious or is not in good faith or the complaint has been made more than 12 months after the complainant became aware of the matter then the NZHRC has the right to dismiss the complaint. ${ }^{149}$ If a complaint is not resolved by the NZHRC then a complainant has the right to apply to the Human Rights Review Tribunal. The Tribunal will only have jurisdiction if the complainant has first attempted to resolve the issue through the alternative dispute resolution methods imposed by the NZHRC. ${ }^{150}$

The case can be taken to the Tribunal by the Office of Human Rights Proceedings on behalf of a complainant or by the complainant themselves, provided they have first complained to the NZHRC. ${ }^{151}$ Legal aid can be accessed for cases before the Tribunal providing the standard criteria are met. ${ }^{152}$ Any party to a proceeding may appeal the Tribunal's decision through the courts in the usual manner. ${ }^{153}$ The Tribunal also has the power to enforce settlements that have been breached. ${ }^{154}$

Rather than focusing on mediation and confidential conciliation services, the UK Commission is more focused on investigation and assessment of the law. The UK Commission in their most recent strategic plan has outlined that they will focus on funding discrimination cases and intervening in other legal proceedings going forward. ${ }^{155}$ The UK Commission views this as the best way to help improve the lives of many in setting new

\footnotetext{
$146 \quad$ Human Rights Act, s 77(2)(a).

$147 \quad$ Human Rights Law Human Rights Act (online ed) at [77.02].

$148 \quad$ Human Rights Act, s 85.

149 Human Rights Act, s 80(2) and 80(3)(b).

$150 \quad$ Human Rights Act, 92B(1)(c).

151 Human Rights Act, s 92B.

152 Legal Services Act 2011, s 7(1)(e)(v).

153 Human Rights Act, ss 123(2) and 124 and Rishworth and others, above n 104, at 396.

$154 \quad$ Human Rights Act, s 92B(4).

155 Equality and Human Rights Commission, Strategic Plan 2012-215 at [27].
} 
precedent. ${ }^{156}$ While acknowledging that the parties could resolve the disputes themselves there is no bar to taking proceeding to the County Court. The United Kingdom does not have a specialised tribunal to deal with general discrimination claims.

\section{Remedies}

While settlement agreements may include financial compensation the Tribunal has the power to award damages where there has been unlawful discrimination. ${ }^{157}$ When providing damages for humiliation, loss of dignity and injury to feelings, which sexual orientation discrimination cases often will, any damages must have regard to the attitude of the defendant. ${ }^{158}$ The Tribunal must be satisfied on the balance of probabilities that the defendant has engaged in unlawful discrimination. ${ }^{159}$

The remedies available to the United Kingdom's County Court are similar to that of the Tribunal. The Court can make a declaration of unlawful discrimination, impose an injunction, award compensation and issue an order for costs. ${ }^{160}$ If there are facts from which the Court could decide that there was discrimination and there was no other explanation the Court must hold that the discrimination existed. ${ }^{161}$

\section{Pilgrim Planet Lodge: A Case Study}

It is important for clarity that the two approaches are not just evaluated by comparisons of the legislation and reasoning of previous cases. A case study will allow the differences of

\footnotetext{
156 Equality and Human Rights Commission "Can the Commission Tell Me If I’ve Been Discriminated Against Under the Act?” <www.equalityhumanrights.com>.

157 HR 83.02 Human Rights Act 1993 s 92I; Butler and Butler, above n 64, at 530 and Laws of New Zealand Discrimination (online ed) at [113]. See generally Simpson v Attorney-General [Baigent's Case] [1994] 3 NZLR 667 (CA).

$158 \quad$ Human Rights Commission v Ocean Beach Freezing Co Ltd (1981) 2 NZAR 415 (EOT) at 428.

$159 \quad$ Laws of New Zealand Discrimination (online ed) at [113].

160 Equality Act 2010 (UK), s 119.

$161 \quad$ Equality Act 2010 (UK), s 136.
} 
approach to become fully evident. In May 2013 Jane Collinson and Paula Knights ("the Collinson-Knights”), a couple engaged to get married, were denied a double bedded room at the Pilgrim Planet Lodge in Whangarei. The Ruskins, the owners, did not recognise same sex relationships due to their religious beliefs. The Ruskins believed that their commercial enterprise was covered by an exception in the NZHRA which allows discrimination on the basis of sexual orientation for the purpose of "residential accommodation which is to be shared with the person disposing of the accommodation, or on whose behalf it is disposed of." 162

The Collinson-Knights complained to the NZHRC. As per the legislative requirements they were directed to confidential mediation. ${ }^{163}$ In this mediation the NZHRC was not obliged to provide legal support to get the parties to better understand their rights. ${ }^{164}$ The Collinson-Knights accepted the mediation settlement, the contents of which are confidential. ${ }^{165}$ The settlement means the complaint was not able to proceed to the Human Rights Review Tribunal. The Ruskins have confirmed they will continue to deny nonheterosexual couples a room. ${ }^{166}$

The wider issue of discrimination against non-heterosexuals and interpretation of the law has not been resolved. Although an apology was provided, the Ruskins are not changing their discriminatory practice and if the couple attempted to stay again they would again be turned away. This case shows that the NZHRC's focus on mediation, while it may provide some movement by the parties, does not help resolve the wider issue of discriminatory practice and interpretation of human rights statutes. Unlike the United Kingdom, where the highest court was able to pronounce publically what was and was not acceptable, New Zealand has been left without such a pronouncement and continuing discrimination. If the

\footnotetext{
$162 \quad$ Human Rights Act, s 54.

$163 \quad$ Human Rights Act, s 77.

164 Human Rights Act, s 77(2)(a).

165 Mathew Dearnaley “Apology, But Gays Still Not Welcome” The New Zealand Herald (online ed, Auckland, 11 July 2013). 
Collinson-Knights had not accepted the apology from the Ruskins and asked the Tribunal to intervene, they may not have been funded by the NZHRC, unlike the Preddy-Halls. ${ }^{167}$

The United Kingdom's approach to discrimination facilitated the denouncement of the discriminatory policy and clarification of non-discrimination law. Whereas the analogous fact situation in New Zealand was confined to confidential mediation.

\section{$V$ Is There a Preferred Approach to Discrimination Claims}

New Zealand has chosen a different path to the United Kingdom in order to settle discrimination claims. With a focus more centred on mediation rather than litigation. In this part of the paper I will analyse the advantages and disadvantages of each approach in meeting the aims of the principle of non-discrimination and building a rights culture.

\section{A Litigation or Mediation: What is the Preferred Approach?}

Formal equality is not sufficient to show respect for the inherent dignity and self-worth of people as they may still be forced to act a certain way to receive equal treatment. ${ }^{168}$ Every man is able to marry whether non-heterosexual or heterosexual if they marry a woman. Thus achieving formal equality. Once it is recognised that substantive equality is the ideal destination the most effective way of achieving this should be employed, to ensure that the principle of non-discrimination is achieved. The fundamental premise of this paper is that there needs to be an increased recognition and respect for non-heterosexual rights, in particular where they conflict with religious rights.

Mediation is often portrayed as the cheaper, faster and more effective way to settle disputes. ${ }^{169}$ Which has prompted mediation and conciliation to be a starting point in many

$167 \quad$ Annual reports form the Human Rights Commission show a steady decline in the number of cases taken by the Office of Human Rights Proceedings, from around 17 per cent of applications in 2009 to 9 per cent of applications in 2013. Butler and Butler, above n 64, at 483.

169 David Spencer and Michael Brogan Mediation Law and Practice (Cambridge University Press, Cambridge, 2006) at 134. 
jurisdiction for discrimination claims. Mediation as a process is more familiar to a wider range of cultures and can be adapted further, compared to a more rigid legal system. ${ }^{170}$ This can make it more attractive to complainants in discrimination cases. The possibility of the mediator reducing the power imbalances is also seen as a positive factor in mediation. There is however, the possibility that the mediator will also carry with them cultural baggage and bias and in some cases can re-enforce the power imbalances that are present in society. ${ }^{171}$ While it may be more likely that a settlement is reached as each party takes the time to understand the other's position, mediation outcomes often reflect interests not rights. ${ }^{172}$ As a consequence more flexible outcomes are often a result. ${ }^{173}$ Whether or not this is a positive depends on the objective of the mediation. Is it a process to ensure that people's rights are being respected or is a process to repair the harm that has been done by the discrimination. The NZHRC regards the Pilgrim Planet mediation as a success, even though the discriminatory policy will continue. Often participants in mediation just want to voice their concerns and be heard by the other party, being vindicated for the wrong, if this happens they may regard the mater as resolved. ${ }^{174}$

Litigation has a more negative perception by the public as costly, in both financial and emotional terms, and as a complex process. ${ }^{175}$ Litigation has been criticised as being too focused on the formal equality outcome. ${ }^{176}$ As Quilter shows there is a possibility that the courts will focus on formal equality to avoid judicial activism. This can also be seen in Bull $v$ Hall where Lord Kerr would not have given a substantive equality interpretation to the Regulations if reg 3(4) were not present. ${ }^{177}$ Nevertheless judicial apprehension should not be the factor which laments litigation to a backup to mediation. When the courts, as they are more willing to now do, focus on substantive equality there are many benefits.

\footnotetext{
170 Tania Sourdin Alternative Dispute Resolution (4th ed, Thompson Reuters, Sydney, 2012) at 67.

$171 \quad$ Sourdin, above $n$ 170, at 85.

172 Sourdin, above n 170 , at 91.

173 Sourdin, above n 170, at 91.

174 Bamforth, Malik and O’Cinneide, above n 31 at 1168 and Sourdin, above n 170, at t 91.

175 Sourdin, above n 170, at 450.

$176 \quad$ Bamforth, Malik and O’Cinneide, above n 31 at 188.

177 Bull v Hall, above n 4, at [62] per Kerr LJ.
} 
Litigation breaks "the link with the individual plaintiff, thereby focusing on collective mechanisms to combat discrimination.”178 It allows for a public pronouncement of rights. Rather than focusing on the interests of the parties' litigation focuses on the rights of those parties. Public pronouncement is needed before any social reform could take place. ${ }^{179}$ Furthermore discrimination laws are not easily interpreted. The enforcement of laws and remedies in discrimination cases should not be underestimated in building a rights culture. ${ }^{180}$

While some people may misunderstand their rights. This does not mean that their complaint has been motivated by malice. ${ }^{181}$ There may have been genuinely hurtful comments or actions from the other party. The individual case may be best resolved through mediation but it does not assist in the understanding of rights more generally. This is because mediations are confidential and there is no obligation on the NZHRC to provide legal advice. The NZHRC's focus is on resolving the complaint whether or not this is done in a consistent manner to previous complaints will be dependent on each of the parties' understanding of their rights or each of the parties' interests as the case may be. Some respondents may choose to make a pragmatic business decision and end the complaint as soon as possible and agree to a settlement which may be too one sided. ${ }^{182}$ With a steady decline in the amount of litigation undertaken by the Office of Human Rights Proceedings and no evidence of a case on the grounds of sexual orientation. These disputes are being relegated to mediation, where there may be a resolution of the specific case but there is no guarantee of their human rights being respected. Outcomes of discrimination claims have a wider reach and more positive societal impact when resolved through discrimination. This is one on the main reasons the UK Commission is focused on litigation to increase awareness of rights and to build a strong rights culture in the United Kingdom.

\footnotetext{
178 Mark Bell Anti-Discrimination Law and the European Union (Oxford University Press, Oxford, 2002) at 147.

$179 \quad$ Spencer and Brogan, above n 169, at 117.

$180 \quad$ Peter Cane Responsibility in Law and Morality (Hart Publications, Oxford, 2002) at 44.

181 Chris Ronalds and Elizabeth Raper Discrimination Law and Practice (4th ed, The Federation Press, Sydney 2012) at 171.

182 Ronalds and Raper, above n 181, at 171.
} 


\section{Conclusion}

The majority of the Supreme Court in their decision in Bull v Hall has taken a real world view of the situation that non-heterosexual couples find themselves. No longer content with continuing the centuries of discrimination and persecution, the majority treated the PreddyHalls' relationship with the dignity and respect it deserves. This was made possible by respecting the principle of non-discrimination and achieving a result that was most consistent with substantive equality. The public pronouncement by the Supreme Court has allowed more people to guide their actions and be resolute in their condemnation of discrimination against non-heterosexuals.

This paper has shown that there are significant differences between New Zealand and the United Kingdom and how the two jurisdictions approach discrimination. Not only in the legislation and process but also in the ability to respect rights and produce greater understanding of non-discrimination laws. The contrast between Bull v Hall and the Pilgrim Planet discrimination has shown that these differences have a significant effect on the outcome and wider consequences of the dispute resolution process.

These differences mean that in New Zealand the resolution of discrimination claims does not impact the wider society. The focus on compulsory mediation means any resolution is limited in its effect to the parties of the dispute. Whether or not this needs to change depends on what New Zealand wants to achieve through its non-discrimination regime. This paper has shown the benefit of allowing discrimination claims to be more readily litigated. The judicial community has shown recently a commitment to substantive equality and as such litigation of discrimination disputes should be available so that understanding of human rights and the dignity and worth of all individuals can be respected.

Word Count: The text of this paper (excluding the cover page, contents page, bibliographic and contextual footnotes, appendix and bibliography) consists of exactly 7993 words. 


\section{VIIAppendix}

\section{A Equality Act (Sexual Orientation Regulations) 2007 (UK)}

3 - Discrimination on the Grounds of Sexual Orientation

1) For the purposes of these Regulations, a person ("A") discriminates against another ("B") if, on grounds of the sexual orientation of B or any other person except A, A treats B less favourably than he treats or would treat others (in cases where there is no material difference in the relevant circumstances).

2) In paragraph (1) a reference to a person's sexual orientation includes a reference to a sexual orientation which he is thought to have

3) For the purposes of these Regulations, a person ("A") discriminates against another ("B") if A applies to B a provision, criterion or practice -

a. which he applies or would apply equally to persons not of B's sexual orientation,

b. which puts persons of B's sexual orientation at a disadvantage compared to some or all others (where there is no material difference in the relevant circumstances),

c. which puts B at a disadvantage compared to some or all persons who are not of his sexual orientation (where there is no material difference in the relevant circumstances), and

d. which A cannot reasonably justify by reference to matters other than B's sexual orientation.

4) For the purposes of paragraphs (1) and (3), the fact that one of the persons (whether or not B) is a civil partner while the other is married shall not be treated as a material difference in the relevant circumstances.

4 - Goods Facilities and Services

1) It is unlawful for a person ("A") concerned with the provision to the public or a section of the public of goods, facilities or services to discriminate against a person (“B”) who seeks to obtain or to use those goods, facilities or services-

a. by refusing to provide B with goods, facilities or services,

b. by refusing to provide B with goods, facilities or services of a quality which is the same as or similar to the quality of goods, facilities or services that A normally provides to-

i. the public, or

ii. a section of the public to which B belongs, 
c. by refusing to provide B with goods, facilities or services in a manner which is the same as or similar to that in which A normally provides goods, facilities or services to-

i. the public, or

ii. a section of the public to which B belongs, or

d. by refusing to provide B with goods, facilities or services on terms which are the same as or similar to the terms on which A normally provides goods, facilities or services to-

i. the public, or

ii. a section of the public to which B belongs.

2) Paragraph (1) applies, in particular, to-

a. access to and use of a place which the public are permitted to enter,

b. accommodation in a hotel, boarding house or similar establishment,

c. facilities by way of banking or insurance or for grants, loans, credit or finance, .

d. facilities for entertainment, recreation or refreshment,

e. facilities for transport or travel, and

f. the services of a profession or trade.

3) (3) Paragraph (1) does not apply -

a. in relation to the provision of goods, facilities or services by a person exercising a public function, or

b. to discrimination in relation to the provision of goods, facilities or services, where such discrimination-

i. is unlawful by virtue of another provision of these regulations or by virtue of a provision of the Employment Equality (Sexual Orientation) Regulations 2003(1) (“the 2003 Regulations”), or

ii. would be unlawful by virtue of another provision of these Regulations or of the 2003 Regulations but for an express exception.

4) (4) For the purposes of paragraph (1) it is immaterial whether or not a person charges for the provision of goods, facilities or services.

\section{B European Convention on Human Rights}

Article 8 - Right to respect for private and family life

1) Everyone has the right to respect for his private and family life, his home and his correspondence.

2) There shall be no interference by a public authority with the exercise of this right except such as is in accordance with the law and is necessary in a democratic society in the interests of national security, public safety or the economic well-being of the 
country, for the prevention of disorder or crime, for the protection of health or morals, or for the protection of the rights and freedoms of others.

Article 9 - Freedom of Thought, Conscience and Religion

1) Everyone has the right to freedom of thought, conscience and religion; this right includes freedom to change his religion or belief and freedom, either alone or in community with others and in public or private, to manifest his religion or belief, in worship, teaching, practice and observance.

2) Freedom to manifest one's religion or beliefs shall be subject only to such limitations as are prescribed by law and are necessary in a democratic society in the interests of public safety, for the protection of public order, health or morals, or for the protection of the rights and freedoms of others.

Article 14 - Prohibition on Discrimination

1) The enjoyment of the rights and freedoms set forth in this Convention shall be secured without discrimination on any ground such as sex, race, colour, language, religion, political or other opinion, national or social origin, association with a national minority, property, birth or other status. 


\section{Bibliography}

\section{A Cases}

1 New Zealand

Attorney-General v Human Rights Review Tribunal (2006) 18 PRNZ 295 (HC).

Human Rights Commission v Ocean Beach Freezing Co Ltd (1981) 2 NZAR 415 (EOT). Ministry of Health $v$ Atkinson [2012] NZCA 184, [2012] 3 NZLR 456.

Northern Regional Health Authority v Human Rights Commission [1998] 2 NZLR 218.

Re Application by AMM and KJO to adopt a child [2010] NZFLR 629 (HC).

Simpson v Attorney-General [Baigent’s Case] [1994] 3 NZLR 667 (CA).

Quilter v Attorney-General [1996] NZFLR 481, 491 (HC).

Quilter v Attorney-General [1998] 1 NZLR 523.

\section{United Kingdom}

Birmingham City Council v Equal Opportunities Commission [1989] AC 1155.

Bull v Hall [2012] EWCA Civ 83, [2012] 1 WLR 2514.

Bull and Another v Hall and Another [2013] UKSC 73 [2013] 1 WLR 3741.

Ghaidan v Godin-Mendoza [2004] 3 WLR 113.

Hall \& Anor v Bull \& Anor [2011] EW Misc 2 (CC) (04 January 2011).

James v Eastleigh Borough Council [1990] 2 AC 751.

$R(E) v$ Governing Body of JFS School [2009] UKSC 15, [2010] 2 AC 728.

$R$ (Williamson) $v$ Secretary of State for Education and Employment [2005] UKHL 15, [2005] 2 AC 246.

\section{South Africa}

National Coalition for Gay and Lesbian Equality v Minister of Justice 1999 (1) SA 6.

\section{European Court of Human Rights}

Bayatyan v Armenia (2011) 54 HER 467 at 494.

Campbell and Cosans v UK (1982) 4 EHRR 293.

Kalac v Turkey (1997) 27 EHRR 552.

Schnorbus v Land Hessen (Case C-79/99) [2000] ECR I-10997. 


\section{B Legislation}

1 New Zealand

Adoption Act 1955.

Civil Union Act 2004.

Human Rights Act 1993.

Legal Services Act 2011.

Marriage Act 1955.

Marriage (Definition of Marriage) Amendment Act 2013.

\section{United Kingdom}

Civil Partnerships Act 2004 (UK).

Human Rights Act 1998 (UK).

Local Government Act 1988 (UK).

Marriage (Same Sex Couples) Act 2013 (UK).

Equality Act (Sexual Orientation) Regulations 2007 (UK).

\section{Treaties}

European Convention on Human Rights.

\section{Books and Chapters in Books}

Nicholas Bamforth, Maleiha Malik and Colm O'Cinneide Discrimination Law: Theory and Context (Sweet \& Maxwell, London, 2008).

Mark Bell Anti-Discrimination Law and the European Union (Oxford University Press, Oxford, 2002).

Andrew Butler and Petra Butler The New Zealand Bill of Rights Act: A Commentary (LexisNexis, Wellington 2005).

Peter Cane Responsibility in Law and Morality (Hart Publications Oxford 2002).

Michael Connolly Discrimination Law (Sweet \& Maxwell, London, 2011).

James Dingemans, Can Yeginsu, Tom Cross and Hafsah Masood The Protections for Religious Rights: Law and Practice (Oxford University Press, Oxford, 2013).

Sandra Fredman Discrimination Law (2nd ed, Oxford University Press, Oxford, 2011). Colin Harvey (ed) Human Rights in the Community: Rights as Agents for Change (Hart Publishing, Oxford, 2005). 
Bruce MacDougall Queer Judgments: Homosexuality, Expression and the Courts in Canada (1 ed, University of Toronto Press, Toronto, 1999).

Karon Monaghan Equality Law (Oxford University Press, Oxford, 2007).

Paul Rishworth and others The New Zealand Bill of Rights (Oxford University Press, Oxford, 2003).

David Spencer and Michael Brogan Mediation Law and Practice (Cambridge University Press, New York, 2006).

Tania Sourdin Alternative Dispute Resolution (4th ed, Thomson Reuters, Sydney, 2012).

Allan Scott Rau, Edward F. Sherman and Scott R Peppet Mediation and Other NonBinding ADR Processes (Foundation Press, New York, 2006).

Chris Ronalds and Elizabeth Raper Discrimination Law and Practice (4th ed, The Federation Press, Sydney 2012).

Kess Waaldijk and Andrew Clapham (eds) Homosexuality: A European Community Issue (Martinue Nijhoff Publishers, London, 1993).

\section{E Journal Articles}

Asher Emanuel “To Whom Will Ye Liken Me, and Make Me Equal? Reformulating the Role of the Comparator in the Identification of Discrimination” (2014) 45 VUWLR 1.

Claire Fenton-Glynn "Replacing One Type of Oppression with Another? Same-Sex Couples and Religious Freedom” (2014) 73(1) CLJ 31.

Vanessa Haggie "Premature Justification: The Place of Comparator Group Analysis in Discrimination Law in Canada and New Zealand” (LLM Research Paper, Victoria University of Wellington, 2012).

Laura-Jane Houghton “Same-sex Marriage: A Perfectionist Liberal Justification” (2000) 7 UCL Juris. Rev. 301.

Ilias Tripiotis “'Alternative Lifestyles' and Unlawful Discrimination: The Limits of Religious Freedom in Bull v Hall” (2014) 1 EHRLR 39.

\section{F Parliamentary Reports}

1 United Kingdom

(24 June 2004) 662 GBPD HL 1354-91.

(12 October 2004) 425 GBPD HC 174. 


\section{G Internet Resources}

“Bristol Gay Couple Win Cornwall B\&B Bed Ban Case” BBC (online ed, London, 18 January 2011).

Equality and Human Rights Commission "Can the Commission Tell Me if I've Been Discriminated Against Under The Act?” < www.equalityhumanrights.com>.

Equality and Human Rights Commission "Our Mission and Values" $<$ www.equalityhumanrights.com>.

"Gay Couple Awarded Damages after Christian Hotel Owners Refused to Let Them Share Double Room” The Telegraph (online ed, London, 18 January 2011).

Mathew Dearnaley “Apology, But Gays Still Not Welcome” The New Zealand Herald (online ed, Auckland, 11 July 2013).

Steve Doughty and Anna Edwards “B\&B Owners’ Right to Bar Gay Couple Crushed By 'Need to Fight Discrimination’ Mail Online (online ed, London, 27 November 2013).

New Zealand Human Rights Commission "About the Human Rights Commission” $<$ www.hrc.co.nz $>$.

\section{H Other Resources}

\section{Speeches}

Lady Hale "The Conflict of Equalities" (Alison Weatherfield Memorial Lecture, Employment Lawyers Association, 10 July 2008).

Nelson Mandela (Speech to Joint Meeting of the Unites States Congress 26 June 1990).

\section{Reports}

New Zealand Law Commission Adoption and Its Alternatives: A Different Approach and a New Framework (NZLC R65, 2000).

Human Rights Commission Annual Report 2013.

Equality and Human Rights Commission, Strategic Plan 2012-215.

\section{Legal Encyclopaedias}

Laws of New Zealand (online ed).

Human Rights Law (online ed). 